\title{
Szerzetesrend a vádlottak padján \\ Ciszterciek a szocializmusban
}

\section{A Religious Order on Trial}

\author{
Cistercians in Socialism
}

\section{Összefoglalás}

Történelmi visszapillantásomban - mint az érintett rend tagja - saját élményeim tükrében idézem föl a múltból rendünk meghurcoltatását, amelyeket részben átéltem, részben kortársként hallottam. Az eseményeket mások is megírták történeti tárgyilagossággal, de talán nem hiábavaló a személyes tanúskodás sem, amikor lassan kihalnak a „nagy idôk tanúi”. A hozzá fúzött megjegyzéseim és értékeléseim sem akarnak csalhatatlan ítéletek lenni emberek felett, inkább plasztikusan szeretném megjeleníteni azokat a kedvezó és kellemetlen személyiségeket, akikkel dolgom volt életemben. A történelmi kor egységének, folyamatosságának, összefüggéseinek bemutatására és egyes időbeli adatok pontossága érdekében sokat merítettem Cúthné Gyóni Eszter 2014-ben írt doktori értekezéséból (A ciszterci rend története Magyarországon 1945 után), aki kutatásait nagymértékben a pártállam biztonsági szerveinek fennmaradt és nyilvánosságra került jegyzókönyveire alapozta. Kötelezôen törekszem a „sine ira et studio” elv, vagyis az elfogulatlanság megórzésére, és sommás általánosítások helyett a minket üldözô szerv szempontjait is próbálom megérteni.

Kulcsszavak: ciszterci rend, szocializmus, kommunista rendszer, iskolák államosítása, békemozgalom

Bán Z. Elızeus dr. O.Cist., ny. zirci perjel (elizeus@ocist.hu). 


\section{Summary}

In this historical retrospection, as a member of the order concerned, I recall the disgraceful harassment our convent underwent as I myself experienced or heard as a contemporary. Although others have also described these events with historical impartiality, personal evidence is perhaps not futile at a point when the last "witnesses of great times" are passing away. With my comments and evaluations I do not intend to pass infallible judgements on people, rather I would like to give graphically render all the likeable and annoying people I met in my life. In order to present unity, continuity and interrelationships in the historical period and in the interest of maintaining the accuracy of certain dates, I rely strongly on the doctoral thesis written by Eszter Cúth Gyóni in 2014 (The history of the Cistercian order in Hungary after 1945), who based her research to a major extent on the minutes of the security organisations of the single-party state. I feel obliged to follow the "sine ira et studio" principle, i.e. to remain unbiased, and instead of summary generalisations I make efforts at understanding the considerations of the organisation that persecuted us.

Keywords: Cistercian order, socialism, communist regime, nationalisation of schools, peace movement

\section{ELôsZó}

Az elmúlt politikai rendszer kiváló példát mutatott arra, hogy hogyan lehet a megtörtént eseményeket egy ideológia szemszögéból beállítani, és az így meghamisított történelmet igazságként bemutatni. Így lehetett nemzedékeket félrenevelni, és talán teljesen ártatlan embereket, intézményeket általános gyúlölet tárgyává tenni. Példaként említem, hogy fiatal ávósokkal is voltam együtt a börtönben. Egyikük, Cs. S. naivul lelkesen magáévá tette a párt eszméit, és buzgólkodásával elérte, hogy ôrmesterként ô lett az egység párttitkára. Mikor azonban az ô falusi szüleit is szorongatták a beszolgáltatásokkal, válságba került a meggyốzôdése. Amikor pedig egy pártgyúlésen a kommunista erkölcs nevében szóvá merte tenni felettesei részegeskedését, hosszú börtönbüntetéssel kellett megtanulnia, hogy más az eszme, és más a gyakorlat. Másoknak akkor nyílt ki a szeme, amikor rádöbbentek, hogy a rendszer bennük sem bízik, és azt kívánták tólük, hogy saját társukról is jelentéseket írjanak. Másképp gondolkodni pedig ellenséges tett.

Mi VOLT A CisZTeRCi REND, És Mi VOLT A BÛ́NE A RENDSZER SZEMÉBEN?

Szovjet szemmel nézve a ciszterci rend egy tömegszervezet, amely keresztény vallási mivoltánál fogva ellenség, ellenforradalmi ideológiai alapon, és veszélyessége különösen abban áll, hogy nemzetközi, mert a központja Rómában van. A gyúlölt Vatikán 
egyik erôs oszlopa Magyarországon, amely kezében tartja az ifjúság nevelését. Ehhez járult még a rend több mint negyvenezer holdas földbirtoka és öt kiváló gimnáziuma, amelyet könnyú volt úgy beállítani, mint a „feudális úri Magyarország” egyik dôzsölő és „népnyúzó” társaságát.

És a valóság? Ez a szerzetesrend a 12. században jött létre olyan szentek életpéldája nyomán, akik elhagyták a világot, hogy imájukkal és munkájukkal szolgálják embertársaik békéjét, lelki, szellemi és anyagi fejlődését. Nagy népszerúségét mutatja, hogy a középkorban 718 ciszterci apátsággal telt meg Európa. (Magyarországon 18 apátság virágzott.) A szerzetesek a maguk részérôl lemondtak a földi örömökrôl Jézus tanítása szerint, egyszerúen, önmegtartóztatóan éltek, de virágzó gazdaságokat hoztak létre, és ezek jövedelméból kulturális értékekkel gazdagították a középkori társadalmat. Föl lehetne vetni, hogy miért nem élnek most is így a szerzetesek. Azon túlmenôen, hogy minden közösségben vannak gyarló emberek is, általános törvényszerúség, hogy amint a friss eszmény, a lelkes élet megszokottá válik, intézménnyé merevedik, a közösségek tagjai is elveszítik lelkesedésüket, és mindinkább gépiesen élik életüket, a szabályok betújéhez ragaszkodnak. Ezért van szükség újra meg újra reformokra, de ezek sokszor az eszményeket is megváltoztatják.

A történelem fejlődésével párhuzamosan rendünk is sokat változott, hiszen igyekezett megfelelni az ôt körülvevô világ újabb kihívásainak. Késôbb be kellett állnia a lelkipásztori munkába, majd a 19. század elején tanítórenddé kellett válnia. A rendre jellemzô volt, hogy minden munkájában igyekezett kiváló teljesítményt nyújtani. A középkorban kialakult nagybirtokrendszer ebben segítségére volt, mert volt miból templomokat építeni, karbantartani, majd iskolákat alapítani, fejleszteni, magas szinten tanárokat képezni. A tanárok közül többen egyetemi katedrát is nyertek. A szerzetesi szellem megóvta a rendet attól, hogy - bár viszonylag kényelmes életet éltek a tanárok, és a múvelt középosztályhoz, az ún. „úri osztályhoz” tartoztak - mégsem az anyagi jólétben keresték boldogulásukat, és nem szakadtak el az egyszerú, szegény néptől. Iskoláinkba alacsony származású diákok is jártak, és szorgalmuk függvényében tandíjmentességet élvezhettek, a tanárok pedig a fizetésükból sokat jótékonykodtak a szegény sorsú diákok felé. A szerzetes tanárok nagy része is egyszerú családból származott, így az apátunk, a kiváló matematikus Endrédy Vendel is magyarországi horvát parasztcsaládból. Tudása, embersége mégis fôpapi méltóságra és fơrendi házi tagságra, az arisztokratákkal egy szintre emelte. Ennek megfelelően igazi nagyúri módon tudott viselkedni megfelelô társaságban, de megmaradt nagyon egyszerú embernek, mindenkihez kedvesnek.

\section{A KOMMUNISTA REZSIM TÁMADÁSA \\ A VALLÁSOS VILÁGNÉZET ELLEN}

Jól tudta mindenki Magyarországon, hogy a Szovjetunió milyen véres üldözéssel rombolta le a maga területén az ortodox egyház templomait, és végezte ki püspökeit, papjait. Mindezt abból az elvból kiindulva, amit még a francia felvilágosodás íróinak eszméiból vettek át, hogy a vallás ópium, a népbutítás eszköze, a kizsákmányolók ha- 
zugsága, amellyel a szegény népet a túlvilági kárpótlás reményével áltatták, hogy ne keljen jogainak védelmére. Ha ez igaz lenne, érthetô és jogos lenne a vallások képviselőinek elítélése és e téveszmék kiirtására való törekvés. De ennek megítélése nem lehet a mesterségesen felbôszített és kelló történelmi ismeretekkel nem rendelkezô tömegek dolga!

A katolikus egyház történetében is voltak méltatlan személyek és súlyosan embertelen gyakorlatok Istenre hivatkozva, az igaz vallás nevében, amelyek Jézus Krisztus tanítását kicsavarva botrányt okoztak, és amelyektól el kell határolnunk magunkat. Ilyenek voltak az erôszakos térítések, az eretnekek és boszorkányok üldözése, a keresztes lovagok kegyetlenkedése, az inkvizíció kínvallató módszere, indiánok kiirtása, négerek rabszolgaságba hurcolása stb., amelyeket nem mentegethetünk, hanem az elkövetôk helyett is szégyellünk. Mindez nem az egyház hivatalos tanítása volt, hanem egyes vezetőinek, sokszor világi fejedelmeknek a túlkapása, amelyek ellen a jobbak már akkor is fölemelték a szavukat. Ezeket a botrányokat évszázadokkal késôbb felróni a már azóta megtisztult mai keresztény nemzedéknek igazságtalan és történelmietlen eljárás, annál is inkább, mert egyoldalú, hiszen az egyháznak a legsötétebb korban is voltak hôsei és vértanúi.

Kellemes meglepetés volt számunkra, amikor a szovjet megszálló hatalom demokráciát hirdetett, és többpárti kormányzást biztosított az országnak. A népszavazáson nagy többséggel a Független Kisgazdapárt gyôzött. Vallásüldözésrôl szó sem esett. De még tartott a háború, amikor a debreceni Ideiglenes Nemzeti Kormány március 18-án kiadta a földreformról szóló 600/1945. sz. rendeletét, amely az egyházi intézményeket, köztük a rendünket is, birtokainak nagy részétôl megfosztotta azzal, hogy ezután állami támogatást kapnak feladataik elvégzéséhez. Az egyházi vezetôk ez ellen nem tettek ellenvetést, és maguk igyekeztek a rendelet értelmében kiosztani a földjeiket. A mi rendünk a mintagazdálkodása révén nagy tekintélynek számított, és észrevételeit miniszteri szinten is tekintetbe vették. Mégis, itt már megmutatkoztak az ütközési pontok. A párt rossz néven vette, hogy Vendel apátunk és Hagyó Kovács Gyula, a rend gazdasági vezetôje felhívta a figyelmet a földosztás egyes szakszerútlenségeire és hátrányos voltára, éppen a földhöz jutott kistermelők szempontjából. A háború utáni általános szegénységben, gépek és állatok hiányában ugyanis ezek a kistermelôk nem tudták megmúvelni a földjeiket. Hagyó Kovács Gyulát az elsők között tartóztatták le a papok közül, mert nem a rendelet szerint végezte a földosztást. Vendel apát pedig hamarosan célpontja lett a párt gyúlöletének, mert a magyar püspöki kar és Mindszenty hercegprímás nevében neki kellett tárgyalnia a kormánnyal. A földreform tehát az elsố csapás volt az egyház, és ezen belül a szerzetesrendek felé, mert a birtok az intézmények fenntartásához szolgált alapul. Ennek elvétele nagy gondba hozta a rendek múködését, és kiszolgáltatottá tette az államnak, amely kárpótlásul támogatást ígért.

A párt - szovjet tapasztalatok alapján - demokratikus jelszavak alatt, a polgári erókkel hajtatta végre lépésról lépésre a maga diktatúráját. Elvették a nagybirtokosok vagyonát, és ezt akkor könnyú volt igazságosnak beállítani, de mindez nem a földhöz juttatott szegények érdekében történt, hanem a kolhozosítás elsô lépéseként: a kistermelôk nem tudtak megélni a földból, így kénytelenek voltak elfogadni a termelôszö- 
vetkezetekbe való tömörülést. Kiszolgáltatottá váltak a pártvezetők akaratának. A „szervezett dolgozók” mozgósíthatók voltak a párt érdekei szerint, akár állami gazdaság, akár tsz alkalmazottai lettek. Hasonlóképp, a tanítórendek célvagyonát elvéve, ezek is kiszolgáltatottak lettek az államnak: ha nem az állam ideológiájának megfelelóen tanítanak, nem kapnak támogatást, vagy le kell mondaniuk az iskoláikról. Mindszenty prímás látta a veszélyt, és tudta, hogy a párt vezetôivel megegyezni nem lehet, mert nem tartják meg a szavukat, ezért mereven ellenállt a vallást érintó minden erôszakos kezdeményezésnek. Ezzel tudták demokráciaellenesnek beállítani. Az állam hamarosan feloszlatta a katolikus egyesületeket, mert nem túrt meg semmiféle szervezetet. „Oszd meg, és uralkodj!” Az iskolában fegyvert rejtettek el, majd „megtalálták”, és ezt használták fel jogcímként, hogy megszüntethessék a kötelező hitoktatást. A prímás elôre látta, hogy ha a szülôk szabad választásán múlik majd a gyermekek hitoktatása, a szülőket könnyú lesz megfélemlíteni, fôképp a „szervezett dolgozókat”, és ezért mozgalmat indított a kötelezó hitoktatás érdekében. Rövid időre sikerült is a kérdést levenni a napirendról.

1947 augusztusában, a hírhedt „kékcédulás választáson” a kormánykoalíció balszárnya előretört, erôszakos „szalámipolitikával” a kisgazdákat kiszorították, a szociáldemokratákat 1948 nyarán Magyar Dolgozók Pártja néven beolvasztották a kommunista pártba, és egyéb adminisztratív intézkedéssel a kommunisták teljes hatalomra jutottak. Az iskolák államosítása elleni tüntetések során, Pócspetriben egy rendôr puskája véletlenül elsült, a lövés megölte a rendôrt, és ezt a hatalom rendôrgyilkosságnak állította be. A plébánost mint felbujtót halálra, majd életfogytiglani elzárásra ítélték. Ezt a balesetet is propagandafogásként használták fel az iskolák államosítása érdekében. Még azon a nyáron a kisgazdapárti Ortutay Gyula vallás- és közoktatásügyi miniszter államosította a szerzetesi iskolákat, december végén pedig letartóztatták Mindszenty prímást. Az államosított iskolák diákjainak nagygyúléseken kellett követelniük a „hazaáruló Mindszenty” példás megbüntetését. Felvonulásokon kellett kiabálni a jelszót: „Munkát, kenyeret, Mindszentynek kötelet!” A püspöki karnak is nyilatkozatban kellett elítélnie Mindszenty politikáját, és húséget tennie a kormány felé.

\section{A GISZTERGIEK IS ELÓTÉRBE KERÜLNEK}

A prímás ellen tervezett koncepciós perbe belevonták Baranyai Jusztin ciszterci egyházjogászt is, a Pázmány Péter Tudományegyetem kánonjogprofesszorát. Legitimista érzelmeiért úgy vonták felelôsségre, hogy azzal vádolták, szervezkedésével meg akarta dönteni a köztársaságot, holott a köztársaság kikiáltásától kezdve Mindszentyvel együtt látták, hogy a királyság visszaállításának nincs reális esélye. A tárgyaláson nem tûnt megtört embernek, és az utolsó szó jogán is védte nézeteit. Az Olti-tanács 15 év fegyházra ítélte. (Elôtte 9 cisztercit vettek órizetbe rövid időre.) Mikor 1956 elején kegyelemmel szabadult, a székesfehérvári Papi Otthonba került rövid időre, ahol én akkoriban civil alkalmazottként, házi mindenesként dolgoztam. Megrendítő volt látni a hajdan nagy tudóst, aki olyannyira elvesztette fényes emlékezetét, hogy társalgás közben már hirtelen elfelejtette, kivel is beszél. Érdeklôdéssel (vagy csak finom udvarias- 
sággal) hallgatta, amit én neki a rend helyzetéról elmondtam, de azonnal el is túnt az emlékezetéből. Egy idôsebb rendtárssal, régi jó ismerôsével is társalgott, majd amikor egy percre megakadt a beszéd, és úgy érezte, valamivel folytatni kellene, udvariasan megkérdezte partnerét: „És kedves feleséged onnagysága hogy van?” Próbáltam faggatni, hogy van-e valami betegsége, de ô nem tudott róla. Utólag olvastam egy rabtársa visszaemlékezésében, hogy egy alkalommal az általam is ismert, kegyetlen B. törzsốrmester ököllel úgy az arcába vágott Jusztin atyának, hogy rögtön elterült a földön. (B. törzsốrmester a rabok köztudomása szerint régebben írástudatlan kanász volt. Kegyetlenségével tört utat magának a ranglétrán. Mérhetetlenül gyúlölte a régi világ urait.)

Ha egy politikai rendszer félti is a vívmányait, a köztársaságot, érthetô, hogy veszedelmes ellenfeleit igyekszik elszigetelni, de itt mesterségesen búntényt alkottak egy érzelmi királyhúségból csak azért, hogy a félreállítandó Mindszenty búnlajstromát még súlyosabbá tegyék. Nem elég, hogy Jusztin atyára halálos ítéletet kért az ügyész, még elítélése után is kegyetlenkedtek vele. Sorsa megrázta a rend tagjait, mert ez volt az elsô súlyos ítélet ciszterci ellen. Bizonyára megfélemlítésnek is szánták.

\section{ENDRÉDY VENDEL APÁT ÜGYE}

Vendel apát úr a hercegprímás letartóztatása után számított rá, hogy hamarosan ô is sorra kerül. Ốrá azonban még sok feladat várt. 1939-ben választották meg a magyar ciszterciek élére. A háború, a nyilas uralom, majd a front átvonulása rengeteg gondot jelentett számára. Zirc lakosságának az apátság épületében nyújtott menedéket. Mindszentyvel akkor került közelebbi kapcsolatba, amikor veszprémi püspökké nevezték ki 1944-ben, és így közvetlen felettesévé lett. Mindszenty már 1919-ben megismerte a kommunizmus terrorját, késóbb a nyilasok börtönét, és rendíthetetlenül kiállt a keresztény erkölcsi értékekért. XII. Pius pápa 1945 augusztusában nevezte ki esztergomi érsekké, majd bíborossá. Vendel apát úr teljes tisztelettel zárkózott föl a prímás vezetése mögött, ô pedig adott a zirci apát megfontolt véleményére, tanácsaira. A Mindszenty-per egyik tanúja, a korábban már meghurcolt és megtört Beresztóczy Miklós a vallomásában állította, hogy Mindszenty és Endrédy jó barátok, Endrédy a prímás tanácsadója és nyugati kapcsolatainak egyik szála. Kétségtelen, hogy Vendel apát úr többször felkereste a prímást, Rómából levelet is hozott számára, elôzóleg részt vett a Mária-napok rendezvényein, ahol az iskolák államosítása és a fakultatív hitoktatás bevezetése ellen tiltakoztak a katolikus tömegek.

1948-ban felgyorsultak az események. Az iskolák államosítása után a tanítórendek tagjai munka nélkül maradtak, mert a prímás megtiltotta, hogy tanítást vállaljanak az államosított iskolákban. Tudta ugyanis, hogy a marxista szellemú iskolákban vagy a lelkiismeretükkel kerülnének szembe, vagy hamarosan úgyis elbocsátanák óket. A szerzetesek a lelkipásztori munkát egyelôre szívesen vállalták, a püspökök is készségesen alkalmazták óket, de a kormányzat ehhez nem járult hozzá. Szóba került, hogy a ciszterci rend - Pannonhalmához hasonlóan - önálló egyházmegyévé szervezôdik, így legalább néhány rendtársnak legális lelkipásztori munkát biztosítana, de az állam ehhez sem járult hozzá. 
Az iskolák 1948-as államosítása után is még sok fiatal jelentkezett felvételre a szerzetesrendekbe. Én is ekkor lettem novícius (újonc) Zircen, 17 társammal együtt. Ez örömet is, gondot is jelentett az elöljáróknak. Endrédy Vendel még a háború végén úgy próbálta menteni a rend jövơjét, hogy néhány rendtársat az Egyesült Államokba küldött, hogy megvessék ott a lábukat. A kezdeményezés sok nehézség után bevált: a magyar ciszterciek Dallasban gimnáziumi és egyetemi tanításra vállalkoztak, és új apátságot alapítottak. Közben itthon az állam néhány iskola visszaadását tervezte, valószínúleg annak bizonyítására, hogy Magyarországon nincs vallásüldözés. Rendünkben is felcsillant a remény, hogy két gimnáziumunkat visszakaphatjuk. A párt a szerzetesrendekre bízta ennek eldöntését. A tárgyalás során hangzott el Rákosi Mátyás döntô nyilatkozata, amely nyomán minden remény szertefoszlott:

„Hogy mely rendek hagyassanak meg, ezzel kapcsolatban nekem egyformák a rendek, ugyanúgy, mint az egyházak, bár az a körülmény, hogy az egyik támogat, a másik nem, ezzel kapcsolatban az állam nem lehet közömbös. De nem tapasztaltuk, hogy az egyik rend jobban támogatna bennünket, mint a másik. De egy dolog mégis van: arisztokratikus rendek, mint az Angolkisasszonyok és a Sacré Coeur, ahova szegényember be sem szagolhatott, ne tessék rossz néven venni, ha ezeket nem akarjuk folytatni. A ciszterek rendfónöke, Endrédy 1945 nyarán azt kérte, azonnal adjuk vissza az erdeiket és 4000 hold szántót, mert ôk mangalicatenyésztôk, és megegyeztek a jobbágyaikkal, hozott egy listát is errôl. Késôbb Mindszenty egyik rossz szelleme volt. Ố volt az utolsó idókig a legaktívabb békeellenes. 70 rend közül az ô rendjét, melyet egy ilyen ember vezet, nem tudom támogatni. Engedjék meg, hogy az államnak legyen itt vétójoga, mi liberálisan mondtuk, hogy válogassák ki az iskolákat, de az államnak is legyen bizonyos joga. Én a cisztereket és az Angolkisasszonyokat feltétlenül megvétóznám.”

Apát úr személyét a renden belül is többen támadták, hogy az ô mindszentista merev politikája az oka, amiért az állammal nem tudunk megegyezésre jutni. Egyik budai tanárunk nyíltan a kommunista állam mellé állt, majd elhagyta a rendet - állítólag azért, hogy mentse az apátját: ô volt Horváth Richárd, késôbb a papi békemozgalom vezetôje, majd az Elnöki Tanács tagja is. Apát úr egy rendi gyúlésen felajánlotta, hogy lemond hivataláról, ha ômiatta szenved hátrányt a rend, de a tanács tagjai kiálltak mellette, ô pedig gondoskodott arról, hogy letartóztatása esetén ki legyen a rend kormányzója. Kijelentette itthon és Rómában is, hogy ha letartóztatják, minden nyilatkozatát érvénytelennek kell tekinteni. Tudta ugyanis, már a Mindszenty-perrel kapcsolatban, hogy az ÁVO bizonyos vegyszerekkel úgy tudja befolyásolni a letartóztatottak vallomásait, hogy azok egyszerúen felmondják, amit beléjük diktáltak.

1950-ben a kormány törekvése volt, hogy a püspöki kart megegyezés aláírására bírja, amellyel aztán törvényesíti a pártállam minden egyházellenes intézkedését, másrészt hivatkozási alapul szolgál mindazon egyházi személyek letartóztatására, akik a megegyezést „megszegik”. A püspöki kar már Mindszenty idejében azzal utasította el az állam kívánságát, hogy ilyen átfogó megegyezésre nem jogosult, mert ez az Apostoli Szentszék illetékessége. A kalocsai érsek, Grősz József vezetésével most is egységesen ellenállt a megegyezésnek, csak Grősz helyettese, Czapik Gyula egri érsek hajlott volna rá. Közismert volt ugyanis, hogy az elôzô rezsimben a leventemozgalom mellett állt 
ki, és ez rossz pontnak számított a háború után, így ezt most feledtetnie kellett. A kormány kettôs erôszakcselekménnyel törte meg a püspöki kar ellenállását.

\section{KÖZBEVETÉS：SZERZETESEK ELHURCOLÁSA}

1950. június 9-én éjjel az ÁVO a bajai, pécsi és szentgotthárdi rendházunk lakóit felzörgette, és fél órát engedélyezve a felkészülésre és ötkilós csomag összeszedésére, teherautón a kényszertartózkodási helyükre, a kunszentmártoni karmelita zárdába vitték óket. Miután nem közölték velük előre, hová szállítják óket, így többen attól féltek, hogy Szibériába kerülnek, vagy valahol útközben kivégzik óket. Nagy megkönnyebbülés volt számukra a szíves fogadtatás, amellyel a kis karmelita közösség befogadta óket, és a viszontlátás is a másik két helyrôl odahurcolt rendtársakkal. Az ávósok szigorúan meghagyták, hogy a kolostort el nem hagyhatják, és többször zaklatták óket váratlan létszámellenőrzéssel. A befogadó kis közösségnek igen nagy teher volt ez a zsúfoltság, de a kényszerú vendégek is igyekeztek a legegyszerúbb helyzettel is megelégedni, minden házimunkába bekapcsolódni, és mindnyájuk számára mennél elviselhetôbbé tenni a kényszerhelyzetet. Amint ezt késôbb személyesen is elmondták az ezeket az eseményeket átélố egykori pécsi tanáraim, hamarosan kultúrköröket szerveztek maguk között, és színvonalas elôadásokkal gyarapították egymás tudását. A gyakorlati érzékúek pedig minden szerelést, javítást vállaltak, hogy az anyagi terheket csökkentsék. A falu népe áldozatosan segített az élelmezésükben.

Az állam azzal okolta meg ezt az akciót, hogy a Jugoszláviával kialakult feszültség miatt kell a határ közeléból eltávolítani a „megbízhatatlan elemeket”. Az igazi ok persze a „nép öklének megmutatása”, vagyis a megfélemlítés volt. A végrehajtó ávósok ennek megfelelően sokszor embertelennek mutatkoztak, de akadtak köztük emberségesek is.

Én tehát ekkor novícius voltam Zircen. Édesanyám hozta a hírt Pécsrôl, hogy az elôzó éjjel elhurcolták az ottani szerzeteseket. Ezt hamarosan több oldalról is megerôsítették. Akadt édesanya, aki ezek után hazavitte a fiát, de a legtöbben kitartottunk a hivatásunk mellett. Aztán hallottuk, hogy az éjszakai elhurcolások megismétlôdtek június 18-án, majd július 11-én is. Minden este azzal feküdtünk le, vajon ezen az éjjelen értünk is eljönnek-e? Ez bizony nem kis lelki megpróbáltatás volt számunkra, mégis kitartottunk. Apát úr ezt látva engedélyt szerzett Rómából, hogy a teljes próbaév letöltése nélkül letehessük idóleges (három évre szóló) fogadalmunkat. Június 22-én 15 novícius elkötelezte magát a rend mellett ebben a teljes bizonytalanságban. Ezek után, nagy meglepetésünkre, augusztus 1-én hajnalban arra ébredtünk, hogy teherautók gördülnek be a monostorunk elé mintegy 500 apácával, akiket különbözó zárdákból hurcoltak ide. Apát úrnak kellett intézkednie, hogy nálunk mindnyájan elférjenek, enni kapjanak, és felelôsséget kellett értük vállalnia, hogy nem szöknek meg. Hirtelenjében kiürítettünk minden szabaddá tehető szobát, termet, szalmát hintettünk a padlóra, hogy a nôvéreknek fekvőhelyük legyen, ôk pedig, mihelyt megkapták a helyüket, rögtön munkára jelentkeztek. A kertból kiszedtek minden ehetốt az ebédhez, nekiláttak a feldolgozásának, és közben hangosan imádkozták a rózsafüzért. Ôk is boldogok voltak, 
hogy Szibéria helyett Zirc vendégszeretetét élvezhetik. Vendel apát úr saját lakosztályát is átadta, és nagyon kedvesen gondoskodott az apácákról testi-lelki szükségükben. A fiatal atyák autóval bejárták a környékbeli falvakat, és hozták a jószívú nép által felajánlott élelmiszereket a nagy tömeg ellátására. Az ávósok biztatták az elhurcolt szerzeteseket, hogy lépjenek ki a szerzetükból, és azonnal visszanyerik a szabadságukat, sốt munkát is biztosítanak számukra, de senki sem lett hútlen a fogadalmához.

Az állam másik erôszakos cselekménye, amellyel a püspöki kar ellenállását megtörte, az ún. békemozgalom volt. A hidegháborús nemzetközi helyzetben folyton hangoztatott szólam volt a béke megvédése, de ez is csak eszköze lett a katolikus papság megszervezésének, hogy ezzel nyomást gyakoroljanak a „makacskodó” püspökökre. 1950. augusztus 1-jére papi nagygyúlést hívtak össze Budapestre, amelyen mintegy 300 „pap” jelent meg. Mint késóbb kiderült, akadtak olyanok, akik nem is tudták, hová viszik óket, de voltak parancsszóra kivonultatott ferences fráterek is. A jelenléti íven olyan papok neve is szerepelt, akik internálótáborban sínylődtek, sôt álruhás civileké is. Horváth Richárd „leleplezte” a reakció „rágalomhadjáratát”, és hangsúlyozta, hogy lehetünk egyszerre jó katolikusok és jó állampolgárok. Sokat hangoztatták ebben az idôben, hogy hit és erkölcs dolgában hívek vagyunk Rómához, de a Vatikán politikáját elítéljük. Látható volt, hogy a kormányzat szívesen hozna létre - szovjet mintára olyan nemzeti egyházat, amely a párt függvénye és kiszolgálója. Ez a nyomás kényszerítette rá a püspöki kart, hogy kérje a megegyezést a kormánytól.

A megegyezés lényegében arra vonatkozott, hogy a püspöki kar elismeri az új demokratikus rendet, elítél minden ellene való akciót, az állam pedig vállalja, hogy 18 éven át anyagilag támogatja a lelkipásztori munkát. A megegyezés után hat gimnáziumot visszaadtak három rendnek, és két leánygimnáziumot az Iskolanôvéreknek. Augusztus 19-én dôlt el, hogy a ciszterciek nem kapnak vissza gimnáziumot, és így múködési engedélyüket is elvesztik. Ezen a napon Apát úr még beöltöztette az új novíciusokat.

Szeptember 7-én jelent meg a Magyar Közlönyben az Elnöki Tanács 34/1950. sz. törvényerejú rendelete, amely megvonta a szerzetesek múködési engedélyét, és ezzel 2300 férfi és 8000 nôi szerzetes volt kénytelen elhagyni addigi otthonát. Három hónap állt rendelkezésükre. Minthogy a szerzetesek nem tartották törvényesnek az állam erôszakos intézkedését, és azt is tudták, hogy értékeiket az ellenséges és hozzá nem értô csốcselék tönkre fogja tenni, ezért amit lehetett, igyekeztek elrejteni, vagy megbízható emberek órizetére bízni. Persze ebból is bajuk származott késóbb. Apát úr a növendékeket is szerette volna külföldre menekíteni, de törvényesen ez nem volt megvalósítható, csak életveszélyes illegális határátlépéssel. Ennek megszervezését a határvidékrôl származó unokaöccsére, Paszkál testvérre bízta, és a növendékek önkéntesen vállalkozhattak a veszélyes kalandra. Ez is búnéül számított a késôbbiekben.

\section{ENDRÉdy VENDEL KÁLVÁRIÁJA}

Apát úr nagy tekintély volt a püspökök és a szerzetes elöljárók előtt, sokszor tárgyalt velük meg a kormánnyal. Rendünk külföldi tagjaival is levelezett, persze virágnyelven, de nem tudta, hogy ügynökök jelentik minden lépését. A rend feloszlatása után már 
csak azzal foglalkozott, hogy segítsen, akin tud. Azt is tudta, hogy várható a lefogása, mert már nyáron többször házkutatást tartottak nála, és zirci embereket vallattak róla. Október végén átadta a monostort az állam részérôl megbízott személynek, majd titkárával, Losonczi Timót atyával autón Budapestre utazott, és ott a Központi Szemináriumban kapott ideiglenes szállást. 29-én ugyancsak autóval indult egy rokonához néhány szükséges személyes holmiért, de az ÁVO útközben feltartóztatta, és órizetbe vette Timót atyával együtt. Az Andrássy út 60. pincéjébe vitték, és mindjárt megkezdôdtek a kihallgatások. Ahogy utólag megírta, nagyon megalázó és fájdalmas kínzásokkal akarták kicsikarni belôle a beismerô vallomást, hogy a szocialista államrend megdöntésére szabotázsakciókat végzô szervezetnek állt az élén, kémkedett a Vatikán számára, külföldi valutával üzérkedett, Nyugatra szöktette a rendi növendékeket. E két utóbbit elismerte, de az elsố kettôt nem írta alá. Öt hétig tartottak a kínzások, de nem tudták megtörni. Végül azt mondták, ha nem írja alá, rendtársait, sôt megnevezett nôismerôseit is behozzák, és előtte ugyanígy kínozni fogják. Ezt már valóban nem vállalhatta: aláírta a hazug vádakat.

Az ÁVO azonban nemcsak ôt akarta elintézni, hanem kitaláltak egy kiterjedt bûnszövetkezetet, amelynek fôszereplőjévé Grôsz József kalocsai érseket, a püspöki kar fejét szemelték ki. Ha ôt félreállítják, egyrészt az egész egyházat megcsúfolják, másrészt az ô emberük, Czapik Gyula kerül az élére. Endrédy csak a hatodrendú vádlott lett ebben a nagy színjátékban, de mellé került hetediknek a rend gazdasági vezetôje, a néhány évvel idôsebb Hagyó Kovács Gyula is. A fốpernek 24 mellékpert rendeltek alá, melyekben ott szerepelt a külföldre szöktetett, de elfogott növendékek ügye is, a pálos rend ügye, a kecskeméti vasutasok szervezkedése, valutaügyek stb.

A kemény ítéletek 1951 nyarán születtek meg. Endrédy apát úr 14 évet kapott. Hôsiesen állta a kínzásokat, de a tárgyaláson már úgy vallott, ahogy az ÁVO kívánta. Grôsz érsek is az utolsó szó jogán „bánta búneit, amivel népe ellen vétett”, és Isten bocsánata mellett remélte bíráinak megértő ítéletét. Apát urat a börtönben teljesen elszigetelték mindenkitôl, és sokáig papírt, ceruzát sem kapott. Tudatosan törekedett viszont, hogy szellemi frissességét el ne veszítse ebben a tunyaságban, ezért egyrészt folyamatosan tornáztatta az emlékezetét, másrészt rengeteget számolt fejben, és így oldott meg bonyolult matematikai feladatokat. Amikor hat év után az '56-os forradalom kiszabadította, testben ugyan betegesen (szív, vitaminhiány stb.), de szellemileg egészségesen került ki börtönéból. Mikor a visszarendezéskor újra visszavitték, egészségügyi panaszai miatt már csak a rabkórházba vihették, és ezért maga az állam kezdeményezte, hogy a püspöki kar kérjen számára kegyelmet. Így elengedték a további nyolc évet, de a hátralévô életét felügyelet alatt a pannonhalmi szociális otthonban kellett töltenie. Itt a gondos ápolás helyrehozta, és 86 éves koráig aránylag jó fizikai állapotban, viszonylag szabadon élt. Én is ebben az idôszakban ismertem meg közelebbrôl, amikor ennek az otthonnak az alkalmazottjaként dolgoztam, és nap mint nap vele étkeztem. Szerencsétlen bírái és fegyőrei, akikért mindennap imádkozott, elképzelni sem tudták, milyen szellemi óriás, milyen meleg szívú ember volt a kezükben, akin kiélték vadállati ösztöneiket.

Pannonhalmán igyekezett rendtársainak lelkileg és anyagilag gondját viselni, és a többi ott élô szerzetes is nagyon tisztelte ôt. Az otthonban rendszerint vasárnap délelôtt 
kultúrelôadásokat tartottak, és ezeken ô is többször nagy sikerrel elôadott. Közérthetôen ismertette az akkori tudomány sok érdekes felfedezését, amelyeket ó is külföldi szaklapokból ismert meg. Sokan látogatták meg, neves egyházi és világi személyiségek, köztük egykori, késôbb híressé vált tanítványai. Csodálták emlékezőtehetségét, hogy gimnazistakoruk apró eseményeire is vissza tudott még emlékezni. Most is szívesen segített a bencés diákoknak, ha nem értették a matematikai feladatokat. Emellett derús kedvú maradt, szerette a tréfálkozást. Igazán szeretetre méltó egyéniség volt!

\section{A NÖVENDÉKEK KALANDJA}

1950 augusztusának végén minden növendéknek felvételi kérelmet kellett írnia az egyik püspökhöz (nekem a székesfehérvárihoz), hogy az egyházmegye kispapjai lehessünk. Közben azonban Apát úr értesült arról, hogy kialakult az illegális szökés pontos terve Ausztria felé, és nagy titokban tôlem is megkérdezte egyik társam, vállalkoznék-e a kockázatos kalandra. Félénk gyermek voltam, irtóztam minden szabálytalanságtól, de mivel feltételeztem, hogy az elöljárók örülnének, ha igent mondanék, vállalkoztam rá. Szeptember 5-én vonattal Bósárkányra kellett utaznom Vazul testvérrel, és ott csatlakoznunk a többiekhez. Ott derült ki, hogy huszonketten vagyunk, és három puskás ember vezetésével az éj sötétjében gyalog kell megközelítenünk a „vasfüggönyt”. Az izgalmas út végén, hajnalban sikeresen át is jutottunk a határon (Vazul testvér lemaradt, így csak huszonegyen), de kellő tájékoztatás és némettudás hiányában nyolc testvér, köztük én is, az osztrák csendôrök kezébe került, akik Eisenstadtba kísértek minket, és átadtak a szovjet városparancsnokságnak. A többi tizenhárom testvér sikeresen megérkezett Rómába, majd késôbb Dallasba. Öthetes várakozás után szovjet teherautó Sopronba hozott vissza minket, és átadott a magyar ÁVO-nak. Nem vertek meg ugyan, de állandó ordítozásukkal kellóen megfélemlítettek, és október 11-e éjjelén rabszállító busszal („meseautó”) Budapestre, a Mosonyi utcai ÁVO-ra szállítottak. Az alagsorban magánzárkákba szállásoltak el, ahol a nap folyamán sok ijesztgetéssel készítettek föl az éjszakai kihallgatásokra. A betonpadlós zárkákban csak egy vassodrony volt három pokróccal, de lefeküdnünk nem volt szabad takarodó előtt. Éjjel meg az égô lámpával szemben kellett aludnunk, és a kezünk nem lehetett a takaró alatt. Ha álmunkban a hideg miatt mégis behúztuk a takaró alá, vagy elfordultunk a lámpától, azonnal fölzavartak.

A kihallgatásokra elsố álmunkból ébresztettek fel. Mindig rohannunk kellett, állandóan felhangzott a sürgetés: „Nyomás!” A kihallgatóhelyiségek viszont kellemesen melegek voltak. Rendszerint barátságos hangnemben kezdôdött, de ha valaki tagadni próbált, csúnyán összeverték az előadó tisztek is. A mi esetünkben nem sok gond volt: beismertük, hogy disszidáltunk, és elhitték, hogy nem tudjuk, az elöljárók tudtak-e róla. Tíz nap alatt mindnyájunkkal végeztek, aláírtuk a vallomásunkat, és október 20án átszállítottak a Markó utcai börtön harmadik emeletére, egy közös zárkába. Ez már paradicsomi állapotnak számított az elôzôhöz képest: együtt voltunk, beszélgethettünk, nem zavart senki, napközben is lefeküdhettünk, jó meleg volt, az ávósok viszonylag kedvesek voltak. Viszont szigorú órizetesek voltunk, mindenki mástól elkülönítve. Nem tudtuk, mikor lesz a tárgyalás, és milyen ítélet vár ránk. 
A Markóban kilenc hónapot töltöttünk, és ez intenzív szerzetesi élet volt. Kezdetben arra törekedtünk, hogy az ausztriai éhezés után visszaszerezzük a testsúlyunkat, majd rendszeres tornázással testi erőnket. Aztán kialakult a napirend, amelyhez nem volt elég az ébresztőtôl takarodóig terjedô 15 óra. Korábban kellett ébredni, hogy magánúton ki-ki elvégezze az olvasmányos imaórát, melyben az olvasmányokat elmélkedés helyettesítette. A zsolozsma többi részét közösen imádkoztuk, illetve énekeltük el halkan. A nap nagy része tanulással telt el: összeadtuk tudásunkat latin, görög, német, angol, francia, olasz, horvát nyelven, tanultunk gyorsírást és elméletben autóvezetést. A torna sem maradt ki. Vacsora után esti mese is volt.

1951. július 16-án végre zárt tárgyalásra vittek. Kirendelt védônk a Mindszenty-perból ismert nyugdíjas bíró, Kiczkó Kálmán volt, aki csak annyit tudott védelmünkre felhozni, hogy fiatal korunk miatt miránk még hatással volt a teológia. (Vajon tudta egyáltalán, hogy mi is az a teológia?) Jónás Béla bíró elismerte, nem bizonyított, hogy mi a népi demokrácia ellen beszéltünk volna Nyugaton, de mivel feltételezhetô, 4-4 évet szabott ki ránk, a két legidôsebb hét, illetve 4 és fél évet kapott. Le voltunk sújtva, de amikor hamarosan átvittek a Gyújtôbe, és láttuk, hogy ott mennyi 10-15 éves van, már eltörpült a saját ítéletünk.

A Gyújtô akkori parancsnoka Bánkúti százados volt (egykori ózdi vasmunkás), aki szózatot intézett hozzánk, hogy az ítélettôl függetlenül korábban vagy késóbb szabadulhatunk, a becsületes munkánktól függően. A börtön épülete két háromágú csillagból állt, de ekkor csak a Bal csillag három osztályát laktuk, összezsúfolva: hárman-négyen egy-egy kis zárkában. Én és két társam a Bal 2-ben laktunk, és a székfényezô üzemben dolgoztunk, másik kettô a Bal 1-ben, és a gombüzemben dolgozott, három pedig a Bal 3-ban, és a bakelitüzemben munkálkodott. A norma többnyire olyan magas volt, hogy nemigen lehetett elérni. Ilyenkor viszont fenyegette az embert a kurtavas: este 6-tól éjfélig a „bûnös” a csuklójánál és bokájánál megláncolva a folyosón ült fájdalmasan feszülő izmokkal, kiszolgáltatva az éjszakás órök kegyetlen szórakozásának. Vagy kivonták a munkából, és a zárkában unatkozhatott egyedül.

Az 50-es évek elején a rabtársadalom háborús búnösökból, azaz magas rangú katonatisztekből (többnyire életfogytosok), izgatás címén elítélt papokból (3-5 év) és öszszeesküvố fiatalokból (10-15 év) állt. Elit társaság. Sokat lehetett tanulni tôlük. A szerzetesek számára a börtönélet nem jelentett különösebb nehézséget, mert hasonlított az önként vállalt, önmegtagadó életre, csak a szentmise hiányzott. A poloskák meg az őrök bosszantó különakciói azonban nehezítették a helyzetet. Mégis nagyon sok öröm is adódott, értékes egyéniségek barátsága, érdekes események stb.

1952 őszén áttelepítettek minket Vácra, és kényelmes csillámfejtô munkát kaptunk. 1953 nyarán pedig Tatabányára szállítottak, és bányászok lettünk. Itt a nehéz munka mellett olyan jó körülményeket biztosítottak, hogy ez már gyöngyéletnek számított. Olyan sokat kerestem, hogy kikerült belőle a négyévi rabtartásom költsége, és szabadulásomkor, 1954 júliusában még haza is vihettem belóle. A legfontosabb azonban az volt, hogy ebben az évben már - titokban - mindennap misén vehettem részt. (A rab papok ugyanis a civil bányászoktól behozott szőlő és fehér kenyér felhasználásával, feltúnés nélkül tudtak misézni az udvaron sétálva.) Utólag úgy minôsítettem az egész börtönélményt, 
mint az élet fôiskoláját, ahol rengeteget tanultam, és életem egyik legszebb szakaszaként köszönöm meg a jó Istennek. Senkire nem neheztelek, az ávósokat is inkább sajnálom, és szeretném, hogy utólag fölismerjék, mennyire félrevezette ôket a marxista ideológia.

$$
56-\text { I G }
$$

Míg én „szélárnyékban” éltem a börtönben, semmit nem tudtam arról, hogy a rend további veszélynek van kitéve. A vezetôség illegalitásban is élni akart, felelôsöket nevezett ki, akik egy-egy területen próbálták összetartani a szétszórtan éló rendtársakat. Nem tudták azonban, hogy sok beszervezett ügynökkel vannak körülvéve, akik mindent jelentenek róluk, és csak idô kérdése, mikor csapnak le rájuk. Ebben az idóben az összetartás volt a legnagyobb bún: ha már ketten-hárman összejöttek, kimerítette a „fennálló rend megdöntésére irányul szervezkedés” búntettét, és letartóztatással fenyegetett. A másik bún az apátság értékeinek rejtegetése volt, mivel az állam jogot formált az államosított apátság minden értékére. A harmadik bún pedig a valutázás volt, vagyis a külföldrôl kapott pénzadományok értékesítése a Magyar Nemzeti Bank megkerülésével. Ezen okból több rendtársat is letartóztattak, és ügynöknek próbáltak beszervezni. Néhányan úgy próbáltak menekülni a besúgószereptôl, hogy inkább elhagyták a rendet és megnôsültek.

Ehhez a korszakhoz tartozik két megrendítő gyilkosság is, amelyet ciszterciek ellen követtek el. 1954. február 21-én az utcán a 37 éves Debreczeni Sixtus ciszterci egri plébánost halálra gázolta egy katonai személyautó, amelyet állítólag ittas sofőr vezetett. Hogy nem véletlen közúti balesetrôl volt szó, igazolja, hogy előzóleg megfenyegették a buzgó lelkipásztort, sôt kétszer is megkísérelték autóval elütni, de akkor nem sikerült; most pedig a gázoló sofőrt a büntetéstôl fölmentették. Sixtus atyát már hét évvel korábban, mint nagykarácsonyi plébánost, félholtra verték a kommunisták. Ártatlanul, mert Egerben sem politizált, csak buzgón és mindenkitől szeretve végezte papi munkáját. Semmilyen ürüggyel sem lehetett perbe fogni, így egyszerúen elintézték egy „balesettel”.

A másik gyilkosság a fiatal szentgotthárdi káplánt, Brenner János Anasztázt tüntette el az útból. János az 1950 augusztusában beöltöztetett utolsó zirci noviciátus tagja volt. Anasztáz lett a rendi neve. Én a börtönból szabadulva a gyôri szemináriumban láttam viszont, ahol ô már utolsó évét töltötte, én meg elsôsként kezdtem a kispapi életet. Anasztázt buzgósága és kedvessége miatt mindenki szerette. Fô bûne az volt, hogy nagy hatással volt az ifjúságra. Amikor a püspök az állam követelése ellenére nem akarta elhelyezni, az egyházügyi megbízott kilátásba helyezte, hogy ennek nem lesznek jó következményei. 1957. december 17-én éjfél körül haldoklóhoz hívták a káplánt, és útközben a vaksötét éjszakában többen megrohanták, 32 késszúrással és testének megtiprásával megölték. A hatóság nem találta meg a gyilkosokat. Az egyház vértanúként tiszteli.

Itt jegyzem meg, hogy engem a pécsi püspök és a jóindulatú békepap-irodaigazgatója, múltamat titkolva, fölvett kispapnak 1954 ószén, és a győri szemináriumba küldött tanulni. A tanév végére azonban valahogy kitudódott, hogy szerzetes vagyok, és két társammal együtt azonnal kizártak a szemináriumból. Elôzôleg sok más szerzetesnövendéket ugyanez a sor érte. 
Apát úr lefogása után 'Sigmond Lóránt novíciusmester lett a rend titkos kormányzója. Igyekezett a rendtársakat összetartani, anyagilag is segíteni, és a jövô számára is dolgozott: titokban nevelte a rendi utánpótlást, és gyújtötte az anyagi eszközöket a rend életének újrakezdéséhez. Az 1956-os forradalom során titkos növendékeit kiküldte Dallasba. Az ÁVO 1952 óta már figyelte, de csak 1961. május végén csaptak le rá.

\section{1-ES CISZTERCI PEREK}

Ez az utolsó persorozat felszámolta a ciszterci illegalitást. Az államot elsôsorban az ifjúsággal való foglalkozás érdekelte, emiatt több rendtársat letartóztattak. A vallási szempontok helyett azonban igyekeztek erkölcstelenséget kimutatni, és megbélyegezni a lefogott szerzeteseket, hogy a nép előtt hitelüket, becsületüket tönkretegyék. A személyeket ismerve, teljesen elképzelhetetlen az a vádpont, hogy Palos Bernardin atya az idős Shvoy püspök úrral és Lóránt atyával homoszexuális viszonyban élt. A nyomozó hatóság mégis ki tudta csikarni belólük ennek beismerését. Elsố fokon Lóránt atya a sok búnéért tíz év börtönt kapott, de másodfokon a hazaárulást és a kétrendbeli fajtalankodást ejtették, és hét évre mérsékelték a büntetését. A börtönben veserákja lett, megoperálták, és 1963. április 1-jén elengedték. A pannonhalmi szociális otthonban élt még egy évet. A halálánál jelen lehettem; tanúsítom, hogy úgy élt, szenvedett és halt meg, mint egy szent.

Megdöbbentő, hogy a legkatonásabb egyéniséget, Palos Bernardint is meg tudták törni. Elôzốleg Pécsett volt tankerületi fôigazgató, kiváló cserkész. Az iskolák államosítása után Zircen lett apáti irodaigazgató. Nem volt érzelmes típus, nem is annyira szeretni, mint inkább tisztelni lehetett. Maga volt a megtestesült fegyelem. A szétszóratás után Székesfehérváron élt, és közkedvelt egyházi szónok volt. Igen magvas, rövid beszédei vonzották a híveket. 1963-ban, kétévi börtön után megtörve szabadult, de nemcsak a fajtalankodás vádjával megterhelve, hanem ráadásul ügynöknek is beszervezve. Bár 315 jelentésével senkinek sem ártott, 12 évig kellett ilyen lelki meghasonlásban élnie.

A 1961-es perek többi szereplőjével nem volt közelebbi kapcsolatom, így róluk nem beszélek. Itt az idô azonban, hogy függelékként hozzászóljak az ügynökkérdéshez.

\section{FÜGGELÉK 1 1 : Az ÜGYNÖKKÉRDÉS}

Sok évvel a szocializmus bukása után rendünk még mindig a „vádlottak padján ül” sok ember szemében, mert több tiszteletre méltó rendtagról kiderült, hogy ügynök, azaz besúgó volt az átkos kommunista világban. Én a kérdéshez úgy kerültem közel, hogy elítéltetésem után a Gyújtôben hívatott a D-tiszt (defenzív, kb. kémelhárító) kihallgatásra, és próbálta fölmérni használhatóságom fokát. Csalódást okozhattam neki, mert dühbe jött naiv feleleteim nyomán, és kurtavassal fenyegetőzve elbocsátott. Szerinte hazug fickó voltam, mert nem ismertem be, hogy csak azért akartam pap lenni, hogy az egyház ingyen kitaníttasson - az ô feltételezése szerint. A rabtársaimtól tudtam meg, hogy a D-tiszt minden rabtársaságból próbál egy-két besúgót beépíteni, és velem 
is kísérletezett. Helyettem az egyik testvért valóban beszervezte, édesapjának valami zúrös ügyével megzsarolva. Ô viszont mindent megbeszélt velem, mert nem akart valóban árulóvá válni. Bizony nehéz, idegfeszítô volt ez a kettôs játék, amikor úgy kellett havonta jelentést írnia, hogy a D-tiszt is elégedett legyen, de ô se ártson senkinek. Többször elófordult, hogy az elégedetlen D-tiszt csúnyán megverte. A besúgók hamar kiismerték a kollégáikat, és tudták, ki az igazán veszélyes, aljas „vamzer”, és igyekeztek ártalmatlanná tenni ôket a jelentéseikkel. Csúnya hazudozós világ volt ez.

Késốbb egy idôsebb rendtársam vallotta meg nekem, hogy sok próbálkozás után nem tudott kitérni a követelés elól, és Budapesten egy cukrászdában kellett találkoznia a tartótisztjével. Ott mindenki az ÁVO alkalmazottja volt. Minden asztalnál elgyötört arccal kínlódott valaki a tartótiszt szorításában.

Pannonhalmán egy fiatal tiszt látogatott ki havonta az otthonvezetőhöz, hogy ellenôrizze, mit csinálnak az otthonban élố „veszélyes elemek”: Endrédy, 'Sigmond, Csávossy, Kerkai stb. Ha az otthonvezetó éppen nem volt otthon, nekem kellett ốt fogadnom. Ez a tiszt azonban szerencsére nem volt fanatikus: elfecsegett egy órát, hogy elszámolhassa a kiküldetését, majd távozott. Megengedte az otthonvezetônek, hogy az idôs szerzeteseket - hivatalos múködési engedély nélkül - lelkipásztori kisegítésre kiengedje a környékbeli plébániákra. Mindez a 60-as évek közepén volt.

A szocializmus idején általános félelem uralkodott. Nemcsak a lakosság félt, melyik éjjel tör rá az ÁVO, hanem az ávósok is féltek, egymástól meg a „reakciósoktól” is. Saját biztonságuk miatt akartak mindenról tudni, mindenütt veszélyt szimatoltak, mindenütt védekezni akartak. Ezért voltak olyan agresszívek. Igazából inkább sajnálatra méltók. Kétségtelenül voltak olyan rosszindulatú emberek is, akik képesek voltak kivallatni és feljelenteni társaikat, hogy maguk valami elónyhöz jussanak. Bent a börtönben is előfordult, hogy valaki óvatlanul elmondott valamit a viselt dolgaiból, és a besúgó társa sietett azt jelenteni. A következmény perújrafelvétel lett, és az illetôt kivégezték. Az ilyen ügynökök természetesen megérdemlik a felelősségre vonást. A legtöbbjük azonban nem ilyen volt.

Itt említem meg két kiváló rendtársam nevét, akikből püspök lett, és utólag kiderült róluk, hogy ôket is beszervezték ügynöknek. Az egyik a közkedvelt erkölcstanprofesszor, Zemplén György, tanárom a Hittudományi Akadémián, aki a római Pápai Magyar Intézet rektora lett, majd esztergomi segédpüspökként a Hittudományi Akadémia rektora. Elképzelni sem tudom, hogy ezt a tudós szerzetest mivel tudták megfogni, mert sem a karrier megcsillantása, sem a megfélemlítés nem látszik valószínúnek. Ugyanígy érthetetlen számomra egykori zirci növendéktársam, Kádár Gábor beszervezése, aki veszprémi püspök, majd egri érsek lett. Fiatal korától szeme fénye volt az egri híveknek, és mindenki örült, hogy ô lett az egri érsek. Tudtommal késôbb is mindenki tisztelte és szerette, és betegségben viszonylag fiatalon halt meg.

\section{FÜGGELÉK 2.：A BÉKEPAPOK}

Szomorú, hogy rendünk egyik tagja olyannyira belemerült a szocialista társadalmi rendbe, hogy az egyházüldözố hatalom kiszolgálójaként, Róma tilalma ellenére, együttmúködött vele, képviselôséget vállalt benne, élére állt a papságot megosztó, püspökökre 
nyomást gyakorló békepapi mozgalomnak, és az Elnöki Tanácsban is helyet foglalt. Horváth Richárd jó tanár volt Budapesten, szociálisan gondolkodó ember, jó szerzetes. Érthetetlen, hogyan tudott ennyire hátat fordítani addigi életének. Társát a békemozgalomban, Beresztóczy Miklóst előzóleg megkínozták, így törve meg az akaratát, de Horváthnál ilyenról nem tudunk. Talán nagyravágyás sem jöhetett szóba. Apátjával is tisztelettel beszélt, amikor kérte elbocsátását a rendből. Ha kezdetben úgy is gondolhatta, hogy ez a rendszer sikeresen megvalósítja az eszményi társadalmi rendet, késôbb látnia kellett, hogy olyan diktatúra jött létre, amely hazugságon alapszik, az erószak tartja fenn, amely mérhetetlen károkat okozott, és amely saját vezetôi közül is többeket bitófára vagy börtönbe juttatott. Vajon hogyan lehetett kitartani mellette évtizedeken át?

A békepapok sok gondot okoztak a püspököknek, mert állami barátaikon keresztül befolyásos helyeket, „zsíros plébániákat”, címeket, rangokat igényeltek maguknak. E világi felfogásukkal nem az evangélium tanítását képviselték, és megbotránkoztatták a híveket. Nem eljárni a békegyúléseikre azzal a kockázattal járt, hogy az állam a lelkipásztort eltiltotta a hitoktatástól, vagy megvonta tôle a kongruát, az állami támogatást. Sok, fôleg idősebb pap emiatt volt kénytelen bekapcsolódni a mozgalomba. Elhíresült esemény volt, amikor 1959-ben a budapesti Központi Szeminárium papnövendékei (köztük én is) nem mentek el a békegyúlésre, és ezért az állam az engedetleneket eltávolította a szemináriumból (nagyjából 80\%-át a kispapoknak).

A békepapok által hangoztatott jogcím többnyire az volt, hogy ezzel az együttmúködéssel akarták biztosítani az egyház túlélését. A kispapok viszont azon az állásponton voltak, hogy az egyházat megmenteni nem a mi feladatunk, az az Úr Jézus dolga. Nekünk engedelmeskednünk kell Rómának és a Rómához húséges püspökeinknek, de nem az állam egyházellenes vezetôinek. Voltak viszont olyan békepapok is, akik arra használták fel tekintélyüket, hogy védték fiatal káplánjaik lelkipásztori munkáját, még a különösen kényes területen, az ifjúsággal való foglalkozásban is. Ezek valóban tiszteletet érdemelnek. Mivel a rendünkben Horváth Richárdon kívül nem volt jellemzô a „békés” tevékenység, erról többet nem kell szólnom.

\section{ÖS SZEGZÉS，KIÉRTÉKELÉS}

Amint rövid összeállításomból látható, elég nagy csapást szenvedett a ciszterci rend a szocialista rendszer idején mind anyagiakban, mind személyekben, mind becsületben. Nem mondhatjuk, hogy teljesen ártatlanul, és jár nekünk a mártíromság díszes piedesztálja. Elvesztettük több mint 40 ezer holdas birtokunkat. Ezt viszonylag könnyen odaadtuk, és nem vádol a lelkiismeretünk, hogy rossz gazdák voltunk, tisztességtelenül szereztük, mások kárára rosszul használtuk. 1990-ben plébános voltam abban a faluban, Apátszálláson, amelyet egykori birtokunkon Hagyó Kovács Gyula atya telepített. Öröm volt hallani, hogyan áldják még ma is az emlékét az egykori cselédek utódai, akiknek a szigorú, cselédnyúzóként elítélt „kormányzó úr” ott házat épített, szociálisan gondoskodott a családokról, a házasuló fiatalokról, öregekrôl és betegekrôl abban az idóben, amikor ez még újdonságnak számított a nagybirtokokon. Elvesztettük öt mintagimnáziumunkat, de abban a tudatban, hogy mind jó karban van, sôt Pécsett 
éppen akkor építettünk a diákok közös munkájával olyan versenyuszodát az iskola udvarán, amely a vízi sportok fellendítését szolgálhatta. Talán nem kell bánkódnunk amiatt, hogy túl büszkék lehettünk iskoláinkra. Elvesztettünk sok száz diákot, akik ezután az államosított iskoláinkban tanultak, de mint a rendszerváltás után kiderült, továbbvitték a tôlünk kapott szellemet, nem lettek hútlenek, és nem hoztak szégyent ránk.

A rend tagjainak létszáma 1950-ben kb. 240 fő volt. 1990-ben már csak 40. A természetes halandóságon felül, sajnos, nagy volt a lemorzsolódás, különösen a fiataloknál. Még azok közül is, akik szerencsésen kijutottak Dallasba. Az meg különösen szomorú, hogy mintegy tíz pap a beszervezés miatt hagyta el a hivatását. Az erkölcsi vádakat, meggyőződésem szerint, biztosan elutasíthatjuk, mint rágalmat, de a gyengeséget be kell ismernünk, hogy sokan vállalták el az ügynökszerepet.

A szabadságvesztést hosszabb-rövidebb idôre kb. negyvenen szenvedték el. Amint fentebb láttuk, nem ártatlanul. A rendszerváltás után a bíróság ezeket az ítéleteket mind semmisnek nyilvánította ugyan, de tény, hogy mi, elítéltek vétettünk a szocialista törvények ellen. Én például a társaimmal engedély nélkül hagytam el az országot. Mások rejtegették azokat az értékeinket, amelyeket a szocialista rendszer állami tulajdonba vett. Ismét mások megkárosították a népgazdaságot, mert nem akarták engedni, hogy a külföldrôl nekünk küldött segélyeket lefölözze a Nemzeti Bank. Nem akartuk tudomásul venni, hogy Magyarországon megváltoztak a régi, polgári világ törvényei. Lehet ilyenkor arról beszélni, hogy az egymást váltó politikai rendszerek változó törvényeinek ítélete ellen fellebbezünk a történelem ítélôszékéhez. Ám ez az eszmei fórum is gyarló emberek vélekedésének a függvénye.

Egy alapvetően vallási intézménynél, mint amilyen egy szerzetesrend, helyénvaló, hogy végsố fórumként Isten ítéletét kérdezzük meg. A renden belül is felmerült, hogy az események alakulása is nem azért vett-e ilyen irányt, mert a szerzetesi intézmény, benne a mi rendünk is, lassan hútlenné vált eredeti eszményeihez, Isten szolgálatához? Amint a választott nép történelmében is azért jöttek a csapások, mert életében külsôségessé lett az istentisztelet, és az egy igaz Isten helyett bálványokat, hamis isteneket imádtak, úgy korunk szerzetesi élete is kiüresedett, elvilágiasodott a századok folyamán, e világi érvényesülést keresett Isten tetszése helyett. Nem arról van szó, hogy eltértünk ôseink, alapító szentjeink életmódjától (mert ilyen elgondolás is fölmerült), hiszen a megváltozott keretek között ez szükségszerú volt, hanem a 19. századtól az istenkapcsolatunk sorvadt el. Igaz, ez a 20. században újra fölébredt, de Isten most látta elérkezettnek az idốt, hogy ítéletet tartson fölöttünk. Ố ültetett minket a vádlottak padjára, hogy búnhôdjünk, okuljunk, megtisztuljunk. Isten ítélete mindig szeretetból történik, a javítást, a megtérést, az élet tökéletesedését szolgálja.

A sok veszteség mellett rendünk biztosan gazdagodott, tisztult, erôsödött a kiállott próbák nyomán, hogy egy újabb felvirágzás eljövetelére felkészüljön.

\section{FELHASZNÁLT IRODALOM}

Cúthné Gyóni Eszter (2014): A ciszterci rend története Magyarországon 1945 után. A Ciszterci Rend Zirci Apátsága 1945 és 1981 között. Doktori disszertáció, ELTE, Budapest. 